\title{
Analisis Kesalahan Siswa Berdasarkan Kategori Kesalahan Menurut Watson Dalam Menyelesaikan Soal Komunikasi Matematis Siswa SMP
}

\author{
Nurul Munawaroh ${ }^{1}$, Euis Eti Rohaeti ${ }^{2}$, Usman Aripin ${ }^{3}$ \\ ${ }^{1}$ Mahasiswa Sarjana Pendidikan Matematika IKIP Siliwangi \\ ${ }^{2,3}$ Dosen IKIP Siliwangi \\ ${ }^{1}$ nurulmunawaroh04@gmail.com, ${ }^{2}$ e2rht@yahoo.com ${ }^{3}$ aripin@stkipsiliwangi.ac.id
}

\begin{abstract}
This study was conducted by giving a five description test that has been validated to one of the upper classes. This research was conducted in class VII J SMP NEGRI 1 CILAMAYA WETAN with limited subject ie 6 students with high, medium, and low grade student classification. The results of the research were students' answers analyzed by the Watson error category. And the percentage of student error type in solving the problem of mathematical communication based on categories of error according to Watson is (inappropriate data/ID) including into error which is high enough that is equal to $38 \%$, (inappropriate procedure/IP) including into error which is quite high at 34\%. (omitted conclution/OC) error is included to a fairly low error of $26 \%$. While (ommited data/OD), (response level conflict/RLC), (undirected manipulation/UM), (skills hierarchy problem/SHP), and (above other / AO) of $0 \%$ each, including into very low errors.
\end{abstract}

Keywords: Mathematical Communication, Student Error, Categories Of Error According To Watson

\begin{abstract}
Abstrak
Penelitian ini dilakukan dengan memberikan tes berbentuk uraian sebanyak lima soal yang telah divalidasi kepada salah satu kelas yang lebih atas. Penelitian ini dilakukan di kelas VII J SMP NEGRI 1 CILAMAYA WETAN dengan subjek terbatas yaitu 6 orang siswa dengan kelasifikasi siswa level tinggi, sedang, dan rendah. Hasil dari penelitian ini yaitu berupa jawaban siswa yang dianalisis berdasarkan kategori kesalahan Watson. Dan persentase dari jenis kesalahan siswa yang telah menyelesaikan soal komunikasi matematis berdasarkan dari kategori kesalahan menurut Watson adalah kesalahan data tidak tepat (inappropriate data/ID) termasuk kedalam kesalahan yang cukup tinggi yaitu sebesar 38\%, Kesalahan prosedur tidak tepat (inappropriate procedure/IP) termasuk kedalam kesalahan yang cukup tinggi juga yaitu sebesar 34\%. Kesalahan kesimpulan hilang (omitted conclution/OC) termasuk kedalam kesalahan yang cukup rendah yaitu sebesar $26 \%$. Sedangkan kesalahan data hilang (ommited data/OD), konflik level respon (response level conflict/RLC), manipulasi tidak langsung (undirected manipulation/UM), masalah hirarkhi keterampilan (skills hierarchy problem/SHP), dan juga kesalahan selain ketujuh kategori di atas (above other/AO) masingmasingnya sebesar $0 \%$, termasuk kedalam kesalahan yang sangat rendah.
\end{abstract}

Kata Kunci : Komunikasi Matematis, Kesalahan Siswa, Kesalahan Menurut Kategori Watson

How to cite: Munawaroh, N., Aripin, U., \& Rohaeti, E. E. (2018). Analisis Kesalahan Siswa Berdasarkan Kategori Kesalahan Menurut Watson dalam Menyelesaikan Soal Komunikasi Matematis Siswa SMP. JPMI - Jurnal Pembelajaran Matematika Inovatif, 1 (5), 993-1004.

\section{PENDAHULUAN}

Matematika merupakan ilmu dasar dari segala bidang yang mempunyai peranan penting untuk dipelajari dan merupakan ilmu yang mendasari perkembangan dari ilmu pengetahuan serta teknologi. Oleh sebab itu matematika perlu diajarkan mulai dari tingkat dasar sampai tingkat 
perguruan tinggi. Karena dalam menghadapi perkembangan ilmu pengetahuan serta teknologi yang begitu sangat meningkat saat ini, diperlukan sumber daya manusia yang baik dan mampu berkompetisi secara global. Kompetisi akan menjadi prinsip hidup dalam suatu masyarakat, karena keadaan dunia yang terbuka dan bersaing untuk mengejar kualitas dan keunggulan. Semua ini menuntut setiap manusia itu memerlukan kemampuan berpikir serta berkomunikasi. Hal ini sejalan dengan Suherman (Septiani, 2013) bahwa "Matematika yang dipelajari melalui pendidikan formal mempunyai peranan sangat penting bagi siswa sebagai bekal pengetahuan dalam membentuk sikap dan pola pikirnya."

Sedangkan menurut Novtiar \& Aripin (2017) mengatakan bahwa matematika adalah salah satu ilmu yang mengandalkan proses berpikir. Dalam proses pembelajarannya matematika adalah salah satu matapelajaran yang begitu penting untuk dipelajari. Hal ini bisa terjadi dikarenakan matematika adalah salah satu aktivitas kehidupan manusia yang sering digunakan maksudnya setiap aktifitas manusia pasti menggunakan ilmu matematika, mulai dari ibu rumah tangga, pedagang, pelajar dan lain sebagainya, dan semua pekerjaan melakukan aktivitas matematika itu sesuai dengan kebutuhannya masing-masing.

Komunikasi sangat dekat dengan karakteristik matematika. Kemampuan komunikasi matematik merupakan kemampuan seorang siswa agar dapat menyatakan serta menjelaskan pendapatnya baik secara lisan maupun secara tertulis apa yang ada dalam soal matematika. Komunikasi matematis merupakan kemampuan siswa untuk menjelaskan dan menyampaikan ide-ide atau gagasan matematika yang telah dipelajarinya. Komunikasi matematis merupakan hal yang penting yang harus dicapai dalam proses pembelajaran matematika. Menurut Izzati (Fitriyanti, 2016) Kemampuan komunikasi matematis adalah kemampuan menggunakan bahasa matematika untuk mengeksperesikan gagasan dan argument dengan tepat. Sedangkan menurut Hidayat \& Sumarmo (2013) kemampuan komunikasi mempunyai peranan penting sebagai representasi kemampuan pemahaman konsep, masalah sehari-hari dan aplikasi konsep matematika dalam disiplin ilmu lain

Dan menurut TIM (Elida, 2012) Komunikasi merupakan suatu pengiriman serta penerimaan pesan antara dua orang atau lebih sehingga pesan yang disampaikan bisa dipahami oleh si penerima pesan tersebut. Menurut Abdulhak (Elida, 2012) "Komunikasi diartikan sebagai suatu proses penyampaian pesan dari si pengirim pesan kepada si penerima pesan melalui cara tertentu untuk suatu tujuan tertentu juga. Sedangkan menurut Schoen, Bean, dan Ziebarth (Elida, 2012) mengatakan bahwa kemampuan komunikasi matematik merupakan kemampuan siswa dalam menjelaskan dan mengkontruksikan suatu algoritma dan fenomena dunia nyata baik dalam bentuk grafik, kata-kata atau kalimat, persamaan, tabel dan sajian secara fisik.

Dengan berkomunikasi siswa dapat meningkatkan kosa kata, mengembangkan kemampuan berbicara, menulis ide-ide secara sistematis, dan memiliki kemampuan belajar yang lebih baik. Menurut Rakhmat (Siska, Sudardjo, \& Purnamaningsih, 2003) mengatakan jika orang memiliki rasa rendah diri, maka dia dapat mengalami kesulitan dalam menyampaikan pendapatnya kepada orang yang memiliki kemampuan lebih dari dia serta akan mengalami rasa takut untuk berbicara didepan umum karena takut salah. Menurut Shadiq (Ramellan, Musdi, \& Armiati, 2012) menyatakan bahwa mengkomunikasikan pendapatnya dengan bahasa matematika malah lebih praktis, sistematis, dan efisien.

Sedangkan menurut Qodariiyah \& Rohaeti (2015) mengatakan bahwa komunikasi matematik merupakan suatu proses dalam menyampaikan suatu ide matematik ke bentuk lainnya baik secara lisan atau tulisan. Komunikasi matematika secara lisan terlihat dalam cara guru 
menjelaskan materi, mengajukan pertanyaan, dan menjawab pertanyaan siswa, dan cara siswa menjawab pertanyaan guru atau temannya, serta cara siswa menjelaskan pengerjaan soal matematika. Hal tersebut berbeda dengan komunikasi matematik tertulis, hal ini terlihat dari cara siswa dalam menyelesaikan suatu permasalahan matematika tertulis kedalam suatu jawaban yang ditulisnya.

Kemampuan komunikasi matematis sangat dibutuhkan baik secara intensif agar siswa dapat lebih aktif dalam pembelajaran serta dapat menghilangkan sebagian rasa takut terhadap pembelajaran matematika. Komunikasi matematis juga sangat penting dipelajari karena matematika pada umumnya merupakan bahasa yang banyak akan notasi dan istilah, sehingga setelah mempelajari komunikasi matematis setidaknya siswa dapat memahami suatu konsep matematika yang ada bahkan dapat memanipulasi suatu jawaban berdasarkan konsep matematika yang diketahuinya.

Menurut Barody (Choridah, 2013) ada dua alasan kenapa komunikasi matematis itu penting, yang pertama adalah matematika bukan sekedar alat bantu berpikir saja. Matematika juga dapat membantu dalam menemukan pola, dan menyelesaikan suatu masalah, tetapi matematika juga dapat dikatakan sebagai an invaluable for communicating a variety of ideas, precisely, and succinctly dan yang kedua yaitu matematika merupakan suatu aktivitas sosial pada pembelajaran matematika, misalnya dalam interaksi antar siswa, komunikasi antara guru dengan siswa, komunikasi antara guru dengan siswa merupakan salah satu hal yang penting dalam pembelajaran matemtika agar guru dapat membimbing siswa dalam memahami suatu konsep atau mencari solusi dalam suatu permasalahan yang ada.

Menurut Greenes dan Schulman (Ramellan, Musdi, \& Armiati, 2012) pentingnya komunikasi karena beberapa hal yaitu untuk menyatakan ide melalui percakapan, tulisan, demonstrasi, dan melukiskan dengan cara visual dalam bentuk yang berbeda; memahami, menginterpretasikan dan mengevaluasi ide yang ada dalam bentuk tulisan maupun dalam bentuk visual; mengkonstruksi, memginterpretasi, dan mengaitkan berbagai bentuk representasi ide dan berhubungannya; membuat pengamatan dan konkekture, merumuskan pertanyaan, membawa dan mengevaluasi informasi; menghasilkan dan menyatakan argumen secara persuasif.

Senada dengan yang disampaikan Greenes dan Schulman dan Van de Walle (Ramellan, Musdi, \& Armiati, 2012) menyampaikan bahwa: "Cara terbaik dalam menghubungkan suatu ide adalah dengan mencoba menyampaikan ide tersebut pada orang lain.' Kemampuan komunikasi matematika adalah salah satu hal yang sangat mendukung untuk seorang guru dalam memahami kemampuan siswa dalam pembelajaran matematika. Hal ini didukung oleh NCTM (Ramellan, Musdi, \& Armiati, 2012) mengungkapkan bahwa tanpa komunikasi dalam matematika, seorang guru akan mengalami sedikit kesulitan terhadap siswa agar siswa dapat memahami proses menjawab suatu permasalahan dan mengaplikasikan suatu symbol matematika karena siswa tersebut tidak paham tentang data yang ada bahkan tentang fakta yang dimaksud dalam suatu permasalahan tersebut.

Pentingnya kemampuan komunikasi juga kemukakan oleh Mahmudi (Wijayanti, 2014) dalam penelitiannya bahwa, perkembangan komunikasi merupakan salah satu tujuan pembelajaran matematika serta standar kompetensi lulusan dalam bidang matematika. Melalui suatu pembelajaran matematika, siswa diharapkan agar bisa mengkomunikasikan pendapatnya baik dengan symbol, tabel, diagram, maupun media lain dalam memperjelas suatu keadaan atau masalah yang ada. 
Menurut The Intended Learning Outcomes (Fitriyanti, 2016) kemampuan komunikasi matematis merupakan suatu keterampilan penting dalam bermatematika yaitu kemampuan dalam mengekspresikan ide-ide matematikanya kepada teman, guru dan lainnya menggunakan bahasa lisan maupun tulisan.

Beberapa peran penting komunikasi matematik dalam pembelajaran matematika dikemukakan juga oleh Asikin (Hendriana, Rohaeti, \& Sumarmo, 2017) diantaranya adalah: a) melalui komunikasi ide matematika dapat digali dalam berbagai perspektif; b) mempertajam cara berfikir untuk meningkatkan kemampuan melihat antara konten matematika; c) untuk mengukur pemahaman matemtis; d) mengorganisasi cara berfikir.

Beberapa penelitian yang ada menjelaskan bahwa kemampuan komunikasi matematis siswa Indonesia masih kurang baik. Shadiq (Fatmasuci, 2017) mendapati kenyataan bahwa di beberapa wilayah Indonesia yang berbeda-beda, sebagian besar siswa mendapati kesulitan dalam membaca suatu soal yang berkaitan dalam kehidupan sehari-hari ke dalam bentuk model matematika. Hal ini dapat dikatakan bahwa kemampuan komunikasi matematika siswa di Indonesia masih kurang baik. Demikian pula Izzati \& Suryadi (Fatmasuci, 2017) mendapatkan gambaran lemahnya kemampuan komunikasi siswa dikarenakan dalam pembelajaran bermatematika selama ini masih kurang memberikan perhatian yang lebih terhadap perkembangan kemampuan komunikasi.

Tabel 1. Rata-rata Persentase Menjawab Benar

\begin{tabular}{l|l|l|l}
\hline Negara & Knowing & Applying & Reasoning \\
\hline Singapura & $82 \%$ & $73 \%$ & $62 \%$ \\
Korea & $80 \%$ & $73 \%$ & $65 \%$ \\
Jepang & $70 \%$ & $64 \%$ & $56 \%$ \\
Malaysia & $44 \%$ & $33 \%$ & $23 \%$ \\
Thailand & $38 \%$ & $30 \%$ & $22 \%$ \\
Indonesia & $37 \%$ & $23 \%$ & $17 \%$ \\
Rata-rata & $49 \%$ & $39 \%$ & $30 \%$ \\
\hline
\end{tabular}

Sumber Rosnawati (Fatmasuci, 2017)

Dapat dilihat dari hasil studi diatas menunjukkan bahwa kemampuan matematika siswa Indonesia lebih rendah dari siswa negara lain dalam cakupan Negara yang berada di Asia. Dari Tabel 1 diatas terlihat bahwa siswa di Indonesia masih rendah kemampuan kognitifnya. Padahal kemampuan ini sangat mempengaruhi prestasi belajar matematika siswa. Suatu prestasi belajar yang cukup baik akan menunjukkan kualitas pembelajaran matematika yang baik pula.

Kemampuan komunikasi matematika memiliki pengaruh yang sangat penting dalam pembelajaran matematika. Namun faktanya pembelajaran di sekolah masih banyak yang belum mampu mengembangkan kemampuan komunikasi matematika. Menurut pendapat Lassak (Novianti, Khoirotunnisa, \& Indriani, 2017) menjelaskan bahwa tidak mudah untuk menjadi seorang guru yang profesional yang dapat memfasilitasi siswa dalam meningkatkan kemampuan komunikasi matematisnya. Hal ini dikarenakan prestasi belajar yang dimiliki oleh siswa satu dengan siswa yang lainnya itu berbeda. Sehingga sering munculnya anggapan bahwa matematika itu merupakan matapelajaran yang sulit serta membingungkan. Sehingga dampak dari hasil belajar matematika siswanya masih rendah. 
Serupa dengan rincian indikator dari NCTM , Sumarmo (Elida, 2012) merinci indikator komunikasi matematik kedalam beberapa kegiatan matematik, antara lain: a) menyatakan benda-benda nyata, situasi, dan peristiwa sehari-hari kedalam bentuk model matematika (gambar, table, diagram, grafik, ekspresi aljabar); b) menjelaskan ide dan model matematika (gambar, table, diagram, grafik, ekspresi aljabar) kedalam bahasa biasa; c) menjelaskan serta membentuk pertanyaan matematika yang dipelajarinya. Adapun beberapa saran untuk mengembangkan kemampuan komunikasi matematik diantaranya adalah: a) melatih kebiasaan siswa untuk menjelaskan jawabannya, memberikan tanggapan jawaban dari orang lain, menurut Pugalle (Hendriana et al., 2017) b) melatih siswa berdiskusi, menyatakn, menjelaskan, menggambarkan, mendengarkan, menanyakan serta bekerja sama di dalam kelompok kecil menurut Within (Hendriana et al., 2017).

Kesalahan adalah kekeliruan, perbuatan yang salah merupakan perbuatan yang melanggar hukum dan sebagainya menurut Depdiknas (Malik, 2011). yang dimaksud di sini merupakan kekeliruan yang dilakukan siswa dalam menyelesaikan suatu permasalahan matematika pada pokok bahasan segiempat dan segitiga. Faktor-faktor internal dapat mempengaruhi rendahnya prestasi belajar siswa yang dapat dilihat dari ketidakmampuan siswa untuk menyelesaikan soalsoal matematika serta dilihat dari kesalahan yang dilakukan siswa dalam menyelesaikan soal matematika. Guru melihat kekeliruan yang dilakukan siswa dari kegiatan belajar mengajar di kelas maupun dari hasil pekerjaan siswa dalam tes ataupun ulangan.

Dalam suatu pembelajaran matematika, siswa seringkali melakukan kesalahan-kesalahan, khususnya kesalahan dalam menyelesaikan suatu permasalahan. Kesalahan-kesalahan tersebut bisa disebabkan karena rendahnya pemahaman suatu konsep matematika siswa, ketidaktelitian siswa dalam menghitung, dan lain sebagainya. Menurut Watson (Winarsih, Sugiarti, \& Khutobah, 2015) terdapat 8 kategori kesalahan dalam mengerjakan soal, yaitu: a.) Inappropriate Data/ID yaitu siswa salah dalam memasukkan data; b.) Inappropriate Procedure/IP adalah siswa kurang memahami maksud dari soal; c.) Ommited Data/OD yaitu kehilangan salah satu data atau lebih dari respon siswa; d.) Ommited Conclusion/OC yaitu siswa salah dalam menyimpulkan sebuah masalah; e.) Response Level Conflict/RLC yaitu konflik level respon; f.) Undirected Manipulation/UM adalah suatu jawaban benar dengan alasan yang sangat sederhana dan penuangan yang tidak logis atau acak; g.) Skills Hierarchy Problem/SHP yaitu siswa kurang teliti dalam melakukan perhitungan serta dalam hasil perhitungan; $\mathrm{h}$.) Above Other/AO adalah penulisan data yang salah dan tidak merespon.

Adanya kesalahan penyelesaian dalam menjawab permasalahan matematika ini perlu kita perhatikan. Kesalahan-kesalahan yang siswa lakukan dalam menjawab suatu pertanyaan perlu diidentifikasi, karena informasi yang didapat tentang kesalahan dalam menjawab soal matematika dapat digunakan dalam meningkatkan mutu kegiatan belajar mengajar matematika dan yang akhirkan diharapkan dapat meningkatkan prestasi belajar matematika.

Salah satu matapelajaran yang sering dianggap sulit oleh siswa yaitu geometri dikarenakan siswa membutuhkan pemikiran serta penalaran yang kritis dan memerlukan abstraksi yang logis. Menurut Sutrisno (Malik, 2011) mengatakan bahwa geometri dianggap hal yang sangat penting dipelajari dalam matematika dikarenakan hampir seluruh pembelajaran matematika membutuhkan geometri untuk menyelesaikan suatu permasalahannya. Misalnya dengan geometri siswa bisa menghitung luas suatu trapesium, tinggi sebuah bangunan, jarak yang ditempuh pesawat dari satu kota ke kota lainnya dan masih banyak lagi pertanyaan matematika yang membutuhkan pengetahuan geometrinya. 
Menurut Van Hiele (Malik, 2011) tiga hal utama untuk mempelajari geometri yaitu waktu yang cukup panjang, materi ajar dan metode pengajaran yang diterapkan. Jika hal tersebut tertata dengan baik akan dapat meningkatkan kemampuan berpikir siswa dalam tahapan berpikir yang lebih tinggi lagi. Salah satu pokok bahasan yang ada dalam pelajaran geometri adalah segiempat. Secara keseluruhan, peneliti memilih materi segiempat untuk menganalisis kesalahan siswa dalam menyelesaiakan soal-soal tes kemampuan komunikasi yang berhubungan dengan geometri.

Masih banyak siswa Sekolah Menegah Pertama (SMP) yang cukup mengalami kesulitan dalam belajar geometri. Berdasarkan hasil wawancara peneliti kepada salah satu guru Matematika di sekolah objek penelitian, pada materi pokok segiempat hasil dari rata-rata belajar siswa kelas VII pada tahun ajaran sebelumnya yaitu sebesar 70, sedangkan KKMnya 75. Hal ini menunjukkan bahwa masih rendahnya nilai rata-rata dari hasil belajar siswa pada materi tersebut. Berdasarkan penjelasan di atas dapat disimpulkan bahwa analisis kesalahan siswa dalam mengerjakan soal matematika dapat dijadikan salah satu alternatif yang baik dan cukup bermanfaat dalam memperbaiki pembelajaran matematika. Sehingga kedepannya guru bisa menggunakan strategi yang lebih tepat dalam pembelajaran yang terkait dalam soal-soal segiempat dan segitiga.

\section{HASIL DAN PEMBAHASAN}

\section{Hasil}

Hasil dari analisis data kemampuan komunikasi matematis pada materi segitiga dan segi empat yang didapat dari 6 subyek berbeda adalah sebagai berikut:

\section{a. Subjek 1}

\begin{tabular}{|c|c|c|c|}
\hline \multirow{3}{*}{$\begin{array}{l}\text { Soal } \\
\text { Salah }\end{array}$} & Letak Kesalaha & & \multirow{3}{*}{ penyebabnya } \\
\hline & I $\quad \mathrm{I} O \mathrm{O}$ U & $\mathrm{S} \quad \mathrm{A}$ & \\
\hline & D P D C & $\begin{array}{ll}\mathrm{H} & \mathrm{O} \\
\mathrm{P}\end{array}$ & \\
\hline
\end{tabular}

\begin{tabular}{|c|c|c|}
\hline 1 & $\mathrm{X}$ & $\begin{array}{l}\text { Siswa kurang memahami pertanyaan yang ada dalam } \\
\text { soal, sehingga siswa salah dalam menyimpulkan suatu } \\
\text { masalah. }\end{array}$ \\
\hline 3 & $\mathrm{X}$ & $\begin{array}{l}\text { Siswa salah dalam memasukkan suatu jawaban sehingga } \\
\text { siswa termasuk kedalam kesalahan data yang tidak } \\
\text { tepat. }\end{array}$ \\
\hline 4 & $\mathrm{X}$ & $\begin{array}{l}\text { Siswa kurang memahami pertanyaan yang ada dalam } \\
\text { soal, sehingga siswa salah menyimpulkan sebuah } \\
\text { masalah. }\end{array}$ \\
\hline 5 & $\mathrm{X}$ & $\begin{array}{l}\text { Siswa salah dalam memasukkan suatu jawaban sehingga } \\
\text { siswa termasuk kedalam kesalahan data yang tidak } \\
\text { tepat. }\end{array}$ \\
\hline
\end{tabular}

\section{b. Subjek 2}

\begin{tabular}{|c|c|c|}
\hline \multirow[b]{2}{*}{$\begin{array}{l}\text { Soal } \\
\text { Sala } \\
\mathrm{h}\end{array}$} & Letak Kesalahan & \multirow[b]{2}{*}{ penyebabnya } \\
\hline & $\begin{array}{llllllll}\text { I } & \text { I } & \text { O } & \text { O } & \text { R } & \text { U } & \text { S } & \text { A } \\
\text { D } & \text { P } & \text { D } & \text { C } & \text { L } & \text { M } & \text { H } & \text { O } \\
& & & & C & & \text { P } & \end{array}$ & \\
\hline 1 & $\mathrm{X}$ & $\begin{array}{l}\text { Siswa kurang memahami pertanyaan yang ada dalam } \\
\text { soal, sehingga siswa salah dalam menyimpulkan sebuah } \\
\text { masalah. }\end{array}$ \\
\hline
\end{tabular}




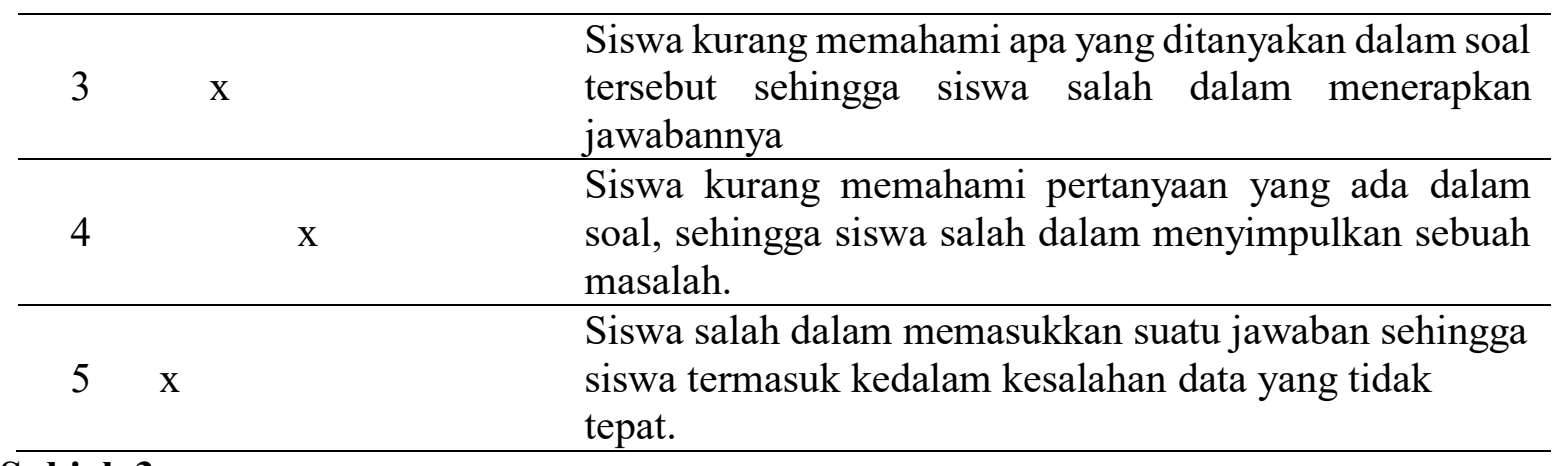

\section{c. Subjek 3}

\begin{tabular}{|c|c|c|}
\hline \multirow{3}{*}{$\begin{array}{l}\text { Soal } \\
\text { Salah }\end{array}$} & Letak Kesalahan & \multirow{3}{*}{ penyebabnya } \\
\hline & 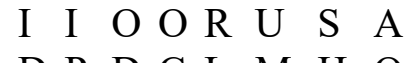 & \\
\hline & $\begin{array}{cccc}\text { D P D C L } & \text { M } & \text { H } & \text { O } \\
& C & & \end{array}$ & \\
\hline 1 & $\mathrm{X}$ & $\begin{array}{l}\text { Siswa kurang memahami apa yang ditanyakan dalam soal } \\
\text { tersebut sehingga siswa salah dalam menerapkan } \\
\text { jawabannya. }\end{array}$ \\
\hline 3 & $\mathrm{X}$ & $\begin{array}{l}\text { Siswa masih salah dalam memahami suatu } \\
\text { pertanyaannya sehingga siswa masih kurang tepat dalam } \\
\text { menjelaskan hasil jawabannya. }\end{array}$ \\
\hline 4 & $\mathrm{x}$ & $\begin{array}{l}\text { Siswa masih salah dalam memahami suatu } \\
\text { pertanyaannya sehingga siswa masih kurang tepat dalam } \\
\text { menjelaskan hasil jawabannya. }\end{array}$ \\
\hline 5 & $\mathrm{X}$ & $\begin{array}{l}\text { Siswa masih salah dalam memahami suatu } \\
\text { pertanyaannya sehingga siswa masih kurang tepat dalam } \\
\text { menjelaskan hasil jawabannya. }\end{array}$ \\
\hline
\end{tabular}

\section{d. Subjek 4}

Letak Kesalahan

Soal I I O O R U S A

Salah D P D C L M H
C P

\begin{tabular}{lll}
\hline 1 & $\mathrm{x}$ & \\
\hline 3 & $\mathrm{x}$
\end{tabular}

Siswa kurang memahami apa yang ditanyakan dalam soal tersebut sehingga siswa salah dalam menerapkan jawabannya.

Siswa kurang memahami pertanyaan yang ada dalam soal, sehingga siswa salah dalam menyimpulkan sebuah masalah.

Siswa masih salah dalam memahami suatu pertanyaannya sehingga siswa masih kurang tepat dalam menjelaskan hasil jawabannya.

Siswa masih salah dalam memahami suatu

$5 x$ pertanyaannya sehingga siswa masih kurang tepat dalam menjelaskan hasil jawabannya.

\section{e. Subjek 5}

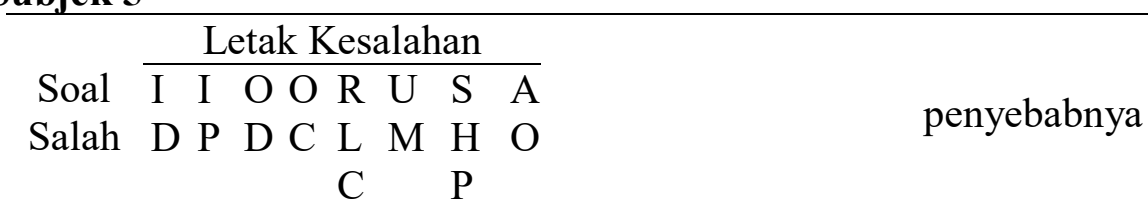




\begin{tabular}{|c|c|c|}
\hline 1 & $\mathrm{X}$ & $\begin{array}{l}\text { Siswa kurang memahami pertanyaan yang ada dalam } \\
\text { soal, sehingga siswa salah dalam menyimpulkan sebuah } \\
\text { masalah. }\end{array}$ \\
\hline 2 & $\mathrm{x}$ & $\begin{array}{l}\text { Siswa masih salah dalam memahami suatu } \\
\text { pertanyaannya sehingga siswa masih kurang tepat dalam } \\
\text { menjelaskan hasil jawabannya. }\end{array}$ \\
\hline 3 & $\mathrm{X}$ & $\begin{array}{l}\text { Siswa kurang memahami apa yang ditanyakan dalam soal } \\
\text { tersebut sehingga siswa salah dalam menerapkan } \\
\text { jawabannya }\end{array}$ \\
\hline 4 & $\mathrm{X}$ & $\begin{array}{l}\text { Siswa kurang memahami apa yang ditanyakan dalam soal } \\
\text { tersebut sehingga siswa salah dalam menerapkan } \\
\text { jawabannya }\end{array}$ \\
\hline 5 & $\mathrm{X}$ & $\begin{array}{l}\text { Siswa kurang memahami apa yang ditanyakan dalam soal } \\
\text { tersebut sehingga siswa salah dalam menerapkan } \\
\text { jawabannya }\end{array}$ \\
\hline
\end{tabular}

\section{f. Subjek 6}

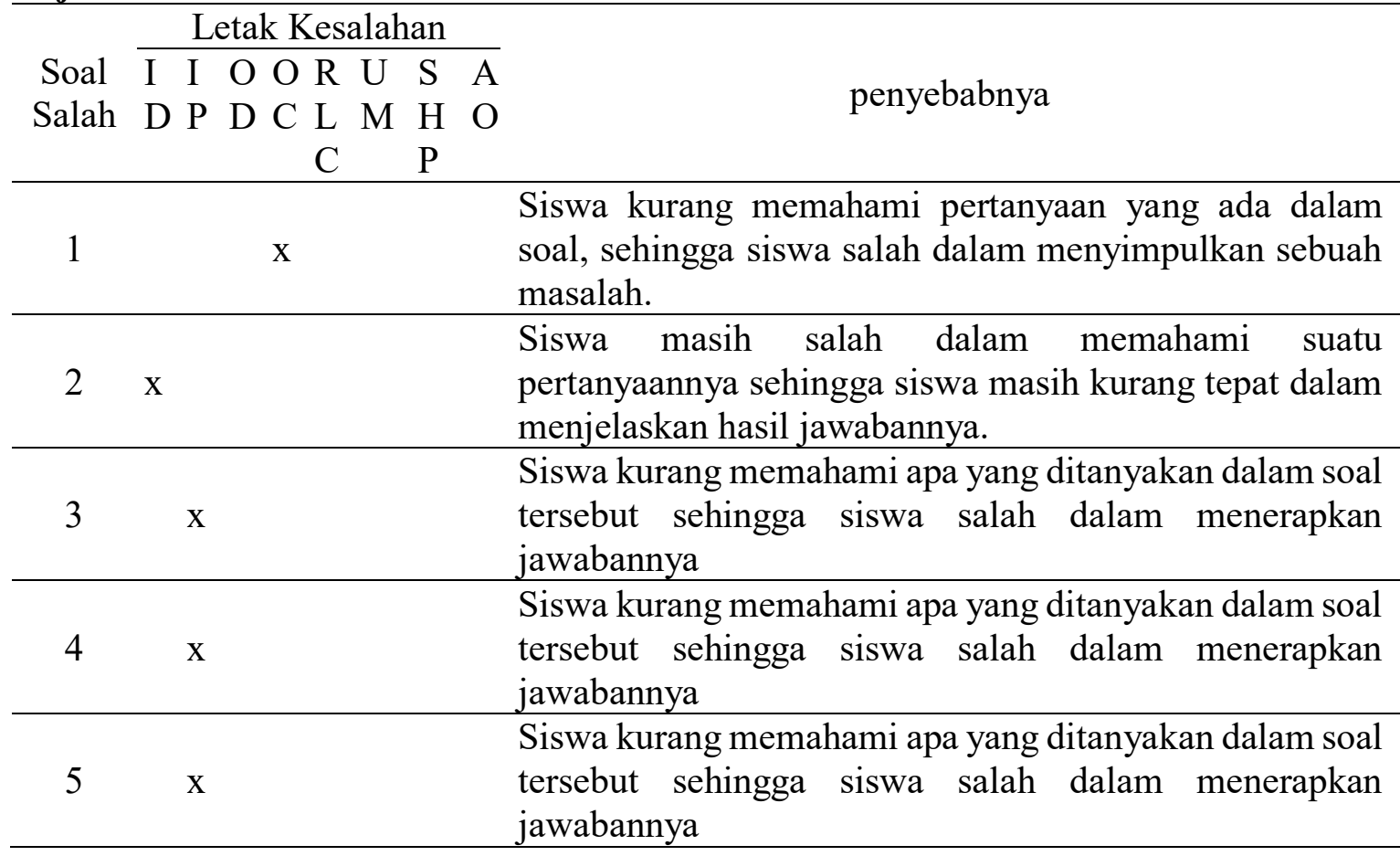

Berikut ini adalah hasil rekapan pada tabel diatas dan juga persentase kesalahan yang dilakukan siswa secara keseluruhan.

\begin{tabular}{cllllllll}
\hline No & \multicolumn{7}{c}{ Jenis Kesalahan } \\
\cline { 2 - 8 } Soal & ID & IP & OD & OC & RLC & UM & SHP & AO \\
\hline 1 & 0 & 2 & 0 & 3 & 0 & 0 & 0 & 0 \\
2 & 2 & 0 & 0 & 0 & 0 & 0 & 0 & 0 \\
3 & 2 & 3 & 0 & 1 & 0 & 0 & 0 & 0 \\
4 & 2 & 2 & 0 & 2 & 0 & 0 & 0 & 0 \\
5 & 4 & 2 & 0 & 0 & 0 & 0 & 0 & 0 \\
\hline jmlh & 10 & 9 & 0 & 7 & 0 & 0 & 0 & 0 \\
\hline$\%$ & $38 \%$ & $34 \%$ & $0 \%$ & $26 \%$ & $0 \%$ & $0 \%$ & $0 \%$ & $0 \%$ \\
\hline
\end{tabular}


Dapat kita lihat pada tabel hasil rekap diatas bahwa jenis kesalahan ID berjumlah 10 siswa yang melakukan kesalahan dari kelima soal yang ada, pada soal no 1 tidak terdapat satupun siswa yang mengalami kesalahan ID tetapi pada soal nomor 2, 3, dan 4 terdapat dua siswa yang mengalami kesalahan pada masing-masing soalnya dan sedangkan pada soal nomor 5 terdapat 4 siswa yang mengalami kesalahan ID. Maka jika dipersentasekan kesalahan ID yang dilakukan adalah sebesar 38\%. Kemudian pada kesalahan IP berjumlah 9 soal yang melakukan kesalahan dari kelima soal yang ada, kesalahan-kesalahan yang dilakukannya terdapat pada 4 soal yang ada selain soal nomor 2, masing-masing jumlah kesalahan yang dilakukannya adalah pada soal nomor 1,4 , dan 5 terdapat masing-masing 2 siswa yang mengalami kesalahan IP, sedangkan soal nomor 3 terdapat 3 siswa yang mengalami kesalahan IP, kesalahan ID dengan kesalahan IP ini tidak jauh beda yaitu hanya selisih 1 siswa saja yang mengalami kesalahannya. Maka jika dipersentasekan kesalahan IP yang dilakukan adalah sebesar 34\%. Dan kesalahan yang dilakukan sisawa juga terdapat pada kesalahan OC yaitu sebanyak 7 siswa yang melakukan kesalahan pada kelima soal yang ada, kesalahan yang dilakukannya terdapat pada soal nomor 1 sebanyak 3 siswa, pada soal nomor 3 sebanyak 1 siswa, dan pada soal nomor 4 sebanyak 4 siswa yang melakukan kesalahan, sedangkan pada soal nomor 1 dan 5 tidak ada. Jika dipersentasekan kesalahan OC yang dilakukan adalah sebesar $26 \%$.

\section{Pembahasan}

Pokok bahasan segiempat dan segitiga merupakan salah satu materi geometri, untuk menyelesaikan soal-soal yang menyangkut geometri diperlukan ketelitian. Dari hasil persentase kesalahan diatas dapat dilihat bahwa kesalahan data tidak tepat (Inappropriate Data/ID) sebesar $38 \%$. Hal ini menunjukkan bahwa kategori kesalahan yang cukup tinggi, kategori persentase ini sejalan dengan pengklasifikasian menurut Winarsih, Sugiarti, \& Khutobah (2015)bahwa jika persentasenya kurang dari atau sama dengan 50\% maka termasuk kedalam tingkat kesalahan yang cukup tinggi, kesalahan data tidak tepat terjadi pada soal nomor 2,3 , 4, dan 5 . Pada soal nomor 2, 3, dan 4 kesalahan data tidak tepat masing-masingnya sebesar 7,5\%, sedangkan pada soal nomor 5 kesalahan data tidak tepat sebesar 15,5\%. Penyebab siswa melakukan kesalahan data tidak tepat ini adalah siswa lupa dengan rumus yang digunakan untuk menjawab soalnya, siswa lupa bagaimana cara mengoprasikannya, siswa salah dalam menafsirkan pertanyaan sehingga siswa salah memasukkan data dalam jawabannya.

Dari hasil persentase kesalahan diatas dapat dilihat bahwa kesalahan prosedur tidak tepat (Inappropriate Procedure/IP) sebesar 34\%. Hal ini menunjukkan bahwa kategori kesalahan yang cukup tinggi, kategori persentase ini sejalan dengan pengklasifikasian menurut Winarsih, Sugiarti, \& Khutobah (2015) bahwa jika persentasenya kurang dari atau sama dengan 50\% maka termasuk kedalam tingkat kesalahan yang cukup tinggi, kesalahan prosedur tidak tepat terjadi pada soal nomor 1, 3, 4, dan 5. Pada soal nomor 1, 4, dan 5 kesalahan prosedur tidak tepat masing-masingnya sebesar 7,5\%, sedangkan pada soal nomor 3 kesalahan prosedur tidak tepat sebesar $11,5 \%$. Penyebab siswa melakukan kesalahan tersebut adalah siswa tidak mengurutkan data, kurang memahami cara menjawabnya, dan siswa kurang memahami maksud dari soal yang ada.

Dari hasil persentase kesalahan diatas dapat dilihat lihat bahwa kesalahan kesimpulan hilang (Omitted Conclunsion/OC) sebesar 26\%. Hal ini menunjukkan bahwa kategori kesalahan yang rendah, kategori persentase ini sejalan dengan pengklasifikasian menurut Winarsih, Sugiarti, \& Khutobah (2015) bahwa jika presentasinya lebih besar dari 20\% maka termasuk kedalam tingkat kesalahan yang rendah kesalahan kesimpulan hilang terjadi pada soal nomor 1, 3, dan 4. Pada soal nomor 1 kesalahan kesimpulan hilang sebesar $15,5 \%$, dan pada soal nomor 3 
kesalahan kesimpulan hilang sebesar 3\%, sedangkan pada soal nomor 4 kesalahan kesimpulan hilang sebesar 7,5\%. Penyebab siswa melakukan kesalahan kesimpulan hilang adalah siswa lupa belum menuliskan suatu kesimpulan, dan kurang teliti ketika membaca perintah suatu soal yang ada.

Sedangkan dari hasil persentase kesalahan diatas dapat dilihat bahwa kesalahan data hilang (Ommited Data/OD), konflik level respon (Response Level Conflict/RLC), manipulasi tidak langsung (Undirected Manipulation/UM), masalah hirarkhi keterampilan (Skills Hierarchy Problem/SHP), dan juga kesalahan selain ketujuh kategori di atas (Above Other/AO) masingmasingnya sebesar $0 \%$. Hal ini menunjukkan bahwa kategori-kategori kesalahan tersebut termasuk kedalam kesalahan yang sangat rendah, kategori persentase ini sejalan dengan pengklasifikasian menurut Arikunto (Winarsih, Sugiarti, \& Khutobah, 2015) bahwa jika presentasinya kurang dari $20 \%$ maka termasuk kedalam tingkat kesalahan yang sangat rendah karena tidak ada satu soalpun termasuk kedalam kesalahan-kesalahan yang bersangkutan.

Dari presentase terbesar pada masing-masing soal, kesalahan yang sering dilakukan oleh siswa adalah kesalahan menggunakan data yang tidak tepat dan menggunakan prosedur yang kurang tepat. Hal ini disebabkan kurangnya pemahaman siswa terhadap materi yang disampaikan, oleh karena itu dalam proses belajar mengajar seorang guru perlu menekankan kembali konsep dan pemahaman siswa pada materi segiempat dan segitiga. Selain itu siswanyapun perlu melakukan latihan-latihan lagi dan perlu memahami lagi tentang segiempat dan segitiga baik cara menyelesaikan soalnya maupun sifat-sifatnya.

\section{KESIMPULAN}

Berdasarkan hasil dan pembahasan dari data yang diperoleh dalam penelitian maka dapat ditarik kesimpulan sebagai berikut.

1) jenis kesalahan siswa dalam menyelesaikan soal komunikasi matematis berdasarkan kategori kesalahan menurut Watson adalah kesalahan data tidak tepat (Inappropriate Data/ID) terjadi pada soal nomor 2, 3, 4, dan 5, Kesalahan prosedur tidak tepat (Inappropriate Data/IP) terjadi pada soal nomor 1, 3, 4, dan 5. Kesalahan kesimpulan hilang (Omitted Conclution/OC) terjadi pada soal nomor 1,3 , dan 4 .

2) Persentase jenis kesalahan siswa dalam menyelesaikan soal komunikasi matematis berdasarkan kategori kesalahan menurut Watson adalah kesalahan data tidak tepat (Inappropriate Data/ID) termasuk kedalam kesalahan yang cukup tinggi yaitu sebesar 38\%, Kesalahan prosedur tidak tepat (Inappropriate Procedure/IP) termasuk kedalam kesalahan yang cukup tinggi juga yaitu sebesar 34\%. Kesalahan kesimpulan hilang (Omitted Conclution/OC) termasuk kedalam kesalahan yang cukup rendah yaitu sebesar $26 \%$.

3) Penyebab siswa melakukan kesalahan dalam menyelesaikan permasalahan pengolahan data berdasarkan kategori kesalahan menurut Watson adalah melakukan kesalahan Innapproprite Data (ID) yang disebabkan karena siswa lupa menulis rumus dalam penyelesaian, siswa salah menafsirkan rumus, dan salah memasukkan data ke dalam suatu rumus. Siswa melakukan kesalahan Innapproprite Procedure (IP) disebabkan karena siswa tidak mengurutkan data, kurang memahami cara mencari sebuah data menggunakan permisalan, dan siswa kurang bisa memahami maksud soal. Siswa melakukan kesalahan Omitted Conclution (OC) karena siswa lupa belum menuliskan kesimpulan, kurang memahami pertanyaan yang ada pada soal, dan kurang teliti ketika membaca perintah soal. 


\section{DAFTAR PUSTAKA}

Choridah, T. R. (2013). Peran Pembelajaran Berbasis Masalah untuk Meningkatkan Kemampuan Komunikasi dan Berpikir Kreatif serta Disposisi Matematis Siswa SMA. Infinity Journal, 2(2), 194-202.

Elida, N. (2012). Meningkatkan Kemampuan Komunikasi Matematik Siswa Sekolah Menengah Pertama Melalui Pembelajaran Think-Talk-Write (TTW). Infinity Journal, 1(2), 178-185.

Fatmasuci, F. W. (2017). Pengembangan Perangkat Pembelajaran Berbasis Masalah Berorientasi pada Kemampuan Komunikasi dan Prestasi Belajar Matematika Siswa SMP. Jurnal Riset Pendidikan Matematika, 4(1), 32-42.

Fitriyanti. (2016). Pengaruh Penerapan Model Problem Based Learning Terhadap Kemampuan Komunikasi Matematis Dan Self Confidence Siswa.

Hendriana, H., Rohaeti, E. E., \& Sumarmo, U. (2017). Hard Skills dan Soft Skills Matematik Siswa. (N. F. Atif, Ed.).

Malik, Q. N. (2011). Analisis kesalahan siswa kelas vii smp 4 kudus dalam menyelesaikan soal matematika pada pokok bahasan segiempat dengan panduan kriteria polya.

Novianti, D. E., Khoirotunnisa, A. U., \& Indriani, A. (2017). Profil Pemecahan Masalah Matematika Dalam Menyelesaikan Permasalahan Pemrograman Linear Ditinjau Dari Kemampuan Komunikasi Matematis. Jurnal Ilmiah Pendidikan Matematika, 6(1), 5359.

Novtiar, C., \& Aripin, U. (2017). Meningkatkan Kemampuan Berfikir Kritis Matematis Dan Kepercayaan Diri Siswa SMP Melalui Pendekatan Open Ended. Jurnal PRISMA Universitas Suryakanca, VI(2), 119-131.

Qodariiyah, L., \& Rohaeti, E. E. (2015). Mengembangkan Kemampuan Komunikasi dan Disposisi Matematik Siswa SMP melalui Discovery Learning. Infinity Journal, 4(2), 237-252.

Ramellan, P., Musdi, E., \& Armiati. (2012). Kemampuan Komunikasi Matematis dan Pembelajaran Interaktif. Jurnal Pendidikan Matematika, 1(1), 77-82.

Septiani, M. D. (2013). Pembentukan Karakter dan Komunikasi Matematika melalui Model Problem Posing Berbantuan Scaffolding Materi Segitiga.

Siska, Sudardjo, \& Purnamaningsih, E. H. (2003). Kepercayaan Diri dan kecemasan Komunikasi Internasional pada Mahasiswa. Jurnal Psikologi, (2), 67-71.

Wijayanti, O. W. (2014). Peningkatan Kemampuan Komunikasi Matematis Melalui Strategi Berbasis Masalah Tipe Relating, Eksperiencing, Appliying, Cooperating, Transfering.

Winarsih, K. A., Sugiarti, T., \& Khutobah. (2015). Analisis Kesalahan Siswa Berdasarkan Kategori Kesalahan Menurut Watson Dalam enyelesaikan Permasalahan Pengolahan Data Siswa Kelas VI SDN Baletbaru 02 Sukowono Jember Tahun Pelajaran 2014 / 2015. Artikel Ilmih Mahasiswa, 1(1), 1-5. M 
1004 Nurul Munawaroh, Euis Eti Rohaeti \& Usman Aripin, Analisi Kesalahan Siswa.... 